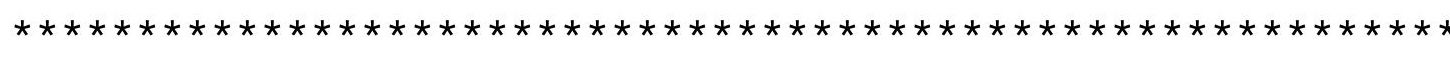

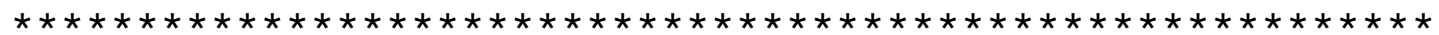

Document-ID: BCCT 408

Patron: BCCT 408

Note: INTERNATIONAL JOURNAL OF REMOTE NOTICE :

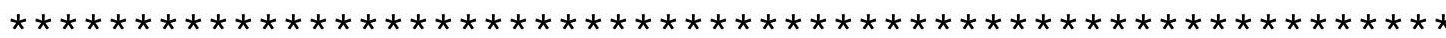

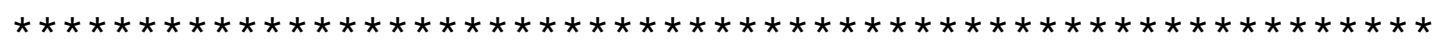

Pages: 18

Printed: 19-05-08 12:05:29

Sender: Ariel/Windows 


\title{
Spectral characteristics of fire scars in Landsat-5 TM images of Amazonia
}

\author{
M. C. PEREIRA and A. W. SETZER \\ Instituto Nacional de Pesquisas Espaciais, INPE, Caixa Postal 515-São José \\ dos Campos, S.P. Brazil, 12201
}

(Received 9 August 1991; in final form 12 June 1992)

\begin{abstract}
This work describes spectral characteristics of fire scars in an area of intense deforestation in the Amazon tropical forest as recorded in the seven Landsat-5 TM spectral channels of an image in 1985. Ground covers were divided into four themes: natural forests, 'capoeiras', pastures in general and fire scars. Single-cell and maximum likelihood classification algorithms were used in the analysis. TM channel 4 was the best to identify fire scars, with digital counts differences in relation to other themes about two times higher than in other channels. Fire scars were also detected in channel 5, with the limitation that recent scars could be mistaken with water. Channels 3 and 7 also contained information about the scars. Results indicated that TM images can be used in automatic detection and assessment of biomass burning in tropical forests, contributing to the understanding of biogeochemical cycles related to the use of fire in these areas. Comparison of the results for channels 3, 4 and 5 in two more TM scenes in 1987 and 1989, showed that minor variations occurred in the spectral definition of the themes, mainly as a result of atmospheric pollution from biomass burning.
\end{abstract}

\section{Introduction}

Satellites of the Landsat series have been used in the study of forest fires. Wightman (1973) mapped fires in east and south tropical Africa and Deschler (1974) found burned areas in Nigeria and to the east that covered up to 90 per cent of a Landsat frame with $32400 \mathrm{~km}^{2}$. Robinove (1975) pointed out that burned areas are easily identified because of their low reflectance. Bruneau and Le Toan (1978) developed a temporal analysis of fires related to shifting agriculture in Thailand. Santos and Aoki (1978) monitored extensive burnings and re-growth of vegetation in a national park close to Brasília, Brazil. In this same country, Chen et al. (1979) showed that automatic digital processing of Landsat data could be used to study vegetation burning and its following recover. In Alaska, Hall et al. (1980) made a similar study and also stressed that Landsat images can replace field inventories in many aspects. In Japan, Tanaka et al. (1983) successfully mapped fires at the Etajima Island with MSS images at a scale of 1:25000. In California, Minich (1983) made a study of Landsat MSS images from 1972 to 1980 and prepared statistics about the distribution of fires and their association with vegetation types. With similar objectives, Allan (1984) made a study in Australia, using in addition, AVHRR and aerial photos. The principal components transformation was used by Richards (1984) to highlight regions of localized change evident in multi-spectral imagery of Landsat TM associated with bushfire damage and with vegetation regrowth following fire burns in Australia. Also in Australia, Richards and Milne 
(1984) used MSS data to analyse fires and the vegetation recover in the Sydney region. Another successful work of temporal analysis of vegetation fires and vegetation recovery was made in Brazil by Ponzoni et al. (1986) with TM data, again at the Brasilia National Park. In Spain, TM was used also to evaluate fires in Catalunia and planning of reforestation (ESA 1987). Also in Spain, Chuvieco and Congalton (1988) used several techniques of digital image processing and visual interpretation to evaluate the use of TM data for mapping and inventory of forest fires. The Yellowstone wildfires of 1988 were noticed by EOSAT (1988) and a visual interpretation was presented for a TM image in a false colour composition with channels 3, 4 and 7. A comparison between estimates using TM Landsat images in channels 3, 4 and 5 and AVHRR NOAA-9 image of channel $3(3.55-3.93 \mu \mathrm{m})$ for the burn area in the Emas National Park, Brazil, in 1988 was done by Pereira et al. (1990). More recently, Brustet et al. (1991) analysed active fires in West African savannas in TM Landsat channels 5 and 7 to study fire characteristics.

Deforestation figures for the tropics during the 1980s point to larger numbers compared to previous decades and have been estimated around 16.9 million hectares per year (WRI 1992). Virtually all forest conversion takes place through the use of fire and the forests are replaced by vegetation with much lower carbon content. As a consequence, the effects of deforestation in the world's carbon cycle and the associated changes in atmospheric chemistry became a major environmental concern. Deforestation accounts for a significant part of carbon emissions from tropical biomass burning, today estimated around 2-5 $\mathrm{Pg} y e a r^{-1}$ (Crutzen and Andreae 1990). In the case of the Amazon forest in Brazil, a ten-fold increase in the amount of smoke from biomass burning with a peak between 1985-1988 has been reported through the analysis of orbital Skylab and Space Shuttle photographs (Helfert and Lulla 1990). The work of Setzer and Pereira (1991) also documented hundreds of thousands of fires in the Brazilian Amazon region during the 1987 dry season using NOAA-9 thermal satellite images based on the technique described by Pereira and Setzer (1992), corroborating unprecedented forest conversion and biomass burning.

Precise estimates of areas impacted by biomass burning can be obtained from high resolution images of environmental remote sensing satellites like Landsat TM and SPOT HRV. These estimates are needed to understand fire ecology, and ultimately the biogeochemical cycles of carbon, nitrogen, phosphorus and many other elements and substances found in the biosphere. This work describes spectral characteristics of fire scars in areas of intense deforestation as recorded by Landsat-5 TM images and which could be used in automatic detection and assessment of biomass burning in tropical forests.

\section{Material and methods}

A digital TM Landsat-5 image of 11 August 1985 for orbit 227, base 67, centred at $10^{\circ} 09^{\prime} \mathrm{S}$ and $56^{\circ} 05^{\prime} \mathrm{W}$, in the northern part of the Brazilian State of Mato Grosso (MT), in the Amazon forest, covering a region with recent deforestation and associated burnings was used (figure 1). The image was recorded in the maximum spatial resolution of $30 \mathrm{~m}$ at about 12:30 UT (09:30 local time) by the Brazilian Space Institute receiving station at Cuiabá, MT, in the seven available channels: (1) $0.45-0.52 \mu \mathrm{m}$; (2) $0.52-0.60 \mu \mathrm{m}$; (3) 0.63-0.69 $\mu \mathrm{m}$; (4) 0.76-0.90 $\mu \mathrm{m}$; (5) $1.55-1.75 \mu \mathrm{m}$; (6) $10 \cdot 04-12 \cdot 5 \mu \mathrm{m}, 120 \mathrm{~m}$ resolution; (7) $2 \cdot 08-2 \cdot 35 \mu \mathrm{m}$. For additional details about TM Landsat see USGS NOAA (1984). 
A sector of the image with 512 lines and columns containing significant burned areas was selected for digital analysis. Figure 2 shows the sector in the image of 11 August 1985. The processing was performed with a multi-spectral image analyser (GE 1975) using mainly its supervised single-cell (SC) and maximum likelihood (ML) classification programmes (Schowengerdt 1983). Both always refer to a range of 256 grey levels. The former provides grey level count limits, average value, standard deviation and number of pixels for ground covers selected in the images. The latter is a statistical classifier algorithm based on a probabilistic density function and separate pixels into any particular classes on a maximum-likelihood basis. The function is obtained for each class previously selected through supervised classification with training samples and is defined by the mean and variance of the grey levels in each class. The algorithm also seeks the lowest mean error when applied to the image, within pre-defined accuracy limits of classification given by a probability threshold (Velasco et al. 1979).

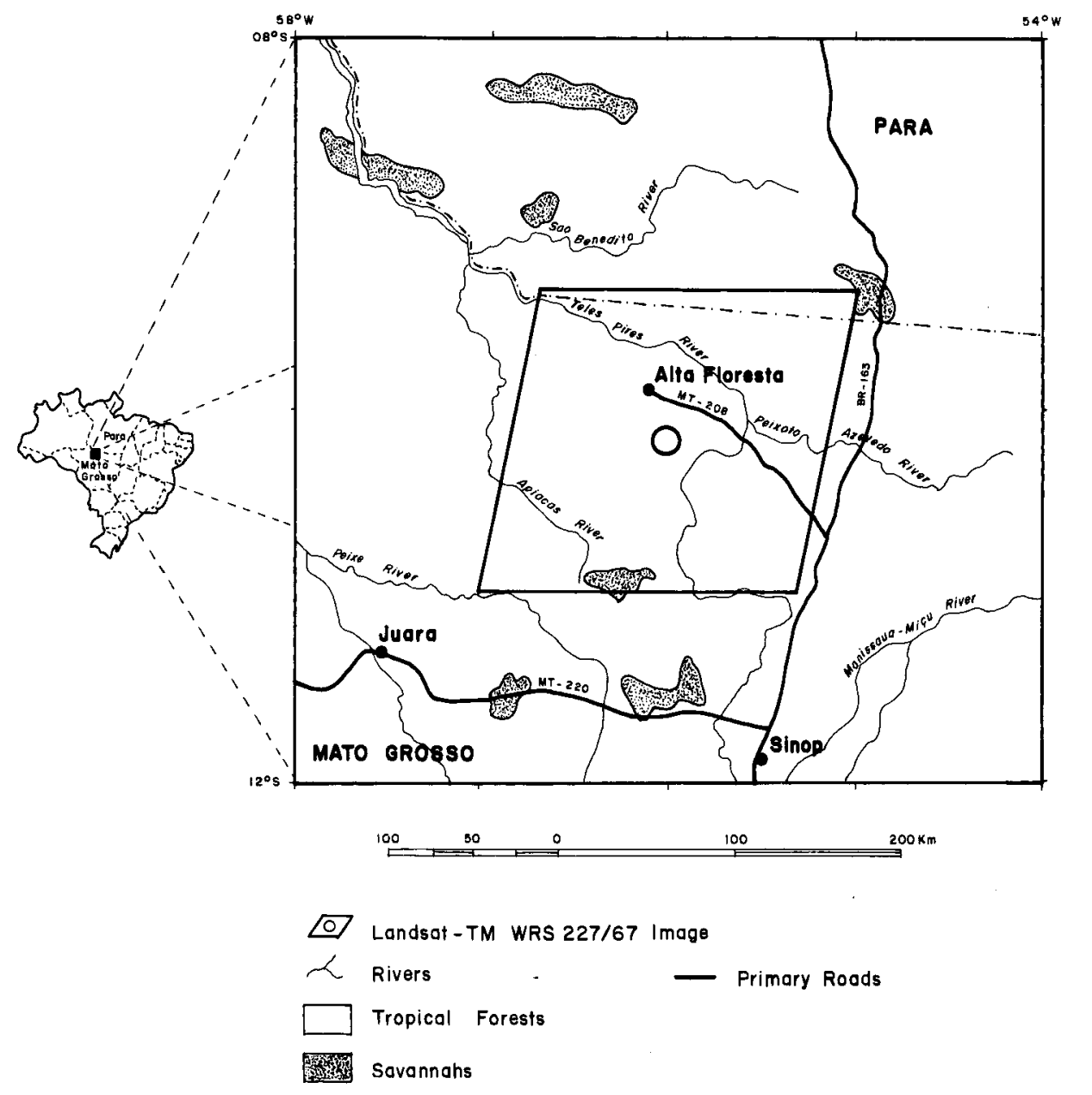

Figure 1. Study area, Alta Floresta, MT, Brazil. 


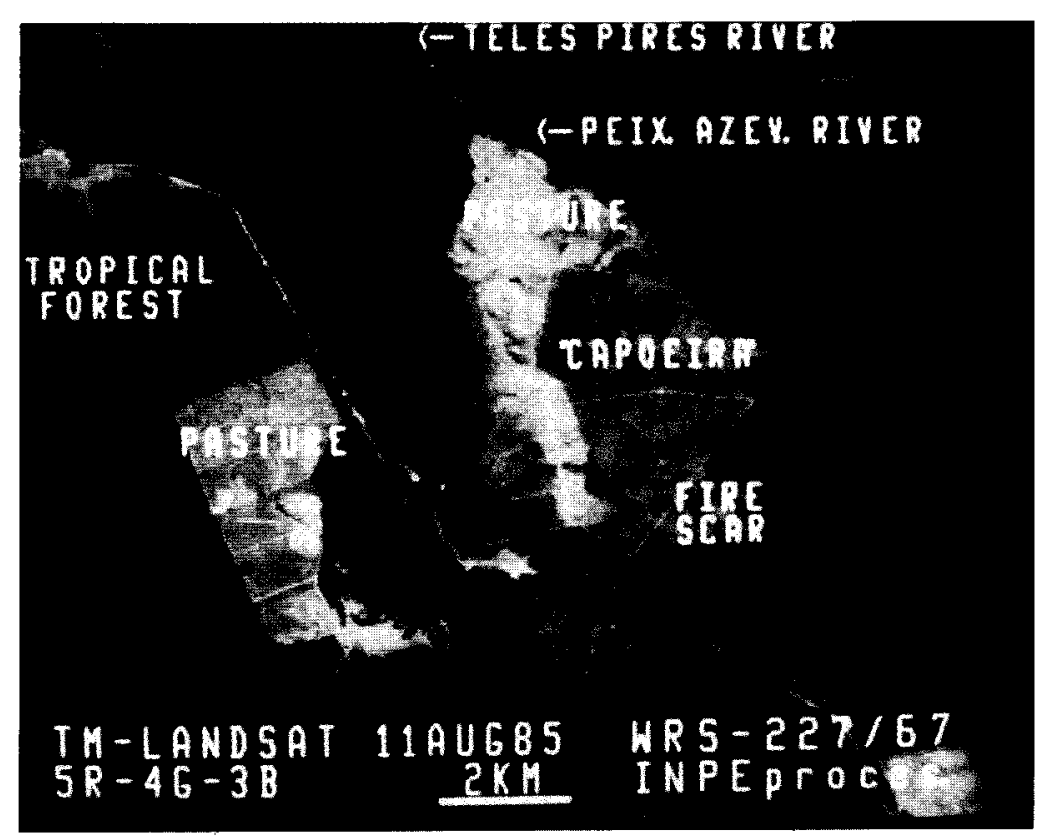

Figure 2. Study sector with 512 by 512 pixels in the Landsat TM image of 11 August 1985 for orbit 227 , base 67 .

Unsupervised analysis was not considered since previous investigation (Santos and Novo 1977) indicated that the classes of interest in this work, natural tropical forests, capoeiras (bushlands with secondary forests), pastures in degraded soils, and burned areas, are spectrally distinct, and also that the above two techniques were the most adequate to detect burned sites. According to Ponzoni et al. (1986), the following colour composition for image display is the most suitable, and was used to produce the figures below: blue for channel 3, green for channel 4 and red for channel 5.

For comparison purposes the TM scenes of the same region imaged on 16 July 1987 and 22 August 1989 were also analysed. A fourth image, of 15 September 1988, was also considered, but excessive smoke from biomass burning prevented useful digital analysis. Spectral statistics of the same themes in the two more recent images were calculated. Correction factors were used to account for differences in solar elevation and distance in the three images, using the equation $E=\left(E_{0} \cos Z\right) / r^{2}$, where $E=$ solar irradiance in a transparent atmosphere, in $\mathrm{wm}^{-2}, E_{\mathrm{o}}=$ solar constant, $1353 \mathrm{w} \mathrm{m}^{-2} ; Z=$ complement of the solar elevation, in degrees; and $r=$ Sun-Earth distance, in astronomical units. Considering the date of the first image, 11 August 1985, as a reference for the solar irradiance value, and assuming that pixel counts are directly proportional to the solar irradiance for same theme surfaces, the multiplying correction factors found were: 1.094 for 16 July 1987 and 0.969 for 22 August 1989.

\section{Results and discussion}

Four main types of ground cover, natural forests, 'capoeiras', pastures in degraded soils and fire scars, were visually selected in the sector of 512 by 512 pixels 
of the 11 August image following the work of Ponzoni et al. (1986) with fire scars and of Santos (1985, personal communication) for pasture and forests. The single cell (SC) algorithm next expanded the classification to all the sector. A second classification was obtained with maximum likelihood (ML) using the classes obtained with SC in order to classify pixels not included by SC in any of the three classes.

A third classification using only ML with 5 and 6 as threshold was also done to reduce the number of pixels not classified. New samples of the four main classes were used to train the ML algorithm. 5892 pixels were used, of which there were 2268 of forest areas, 560 of capoeiras and grasslands, 1420 of pastures in degraded soils and 1644 of fire scars. Results of the classifications are presented in table 1. These values, however, yielded relatively less points not classified and more points wrongly classified by ML. This indicated that the threshold was critical in this study, and a more detailed analysis of the threshold had to be done.

Results of threshold tests for the four main classes are presented in table 2 and figure 3 . The threshold below 3.5 caused an excessive increase of pixels not classified, without improving the performance of classification. Above 6 , the performance remained constant but the confusion in classification increased. The data show that appropriate thresholds are in the $3 \cdot 8$ to $4 \cdot 2$ range. For example, for $4 \cdot 2$, the mean performance is 99 per cent, the mean confusion 0.25 per cent and the mean unclassification 1.4 per cent. Using this threshold the classification produced results with small confusion, which are presented in figure 4 , in table 3 and described below.

Figure 4 shows that the best combination of channels to separate the four classes is that of 4 and 5 since the ellipses in the two-dimensional feature space are more separated than in the plots for other channels. A second combination with good separability of classes is that of channels 3 and 4 . Therefore, since channel 4 is in the two combinations above, one may infer that it is the best one to detect fire scars. This is also seen in table 3 and figure 5, where the mean of the grey levels for fire scars in channel 4 is more distant from the means of other ground covers than in any other TM channels. Table 3 and figure 5 present means and variances obtained for each of the four classes considered in the seven TM channels analysed; they also confirm previous studies (Ponzoni et al. 1986, ESA 1987) that indicated that channels 3,4 and 5 are the best TM channels to study fire scars.

Table 1. Results of single-cell and maximum likelihood classification algorithms.

\begin{tabular}{|c|c|c|c|c|c|c|c|c|}
\hline & \multicolumn{2}{|c|}{ Single-cell } & \multicolumn{2}{|c|}{$\frac{\text { Maxlike* }^{*}}{(\text { threshold }=4 \cdot 5)}$} & \multicolumn{4}{|c|}{ Maxlike** } \\
\hline & $\begin{array}{l}\text { class. } \\
\text { pixels }\end{array}$ & $\begin{array}{c}\text { area } \\
\left(\mathrm{km}^{2}\right)\end{array}$ & $\begin{array}{l}\text { (thresho } \\
\text { class. } \\
\text { pixels }\end{array}$ & $\begin{array}{c}\mathrm{ld}=4 \cdot 5) \\
\operatorname{area} \\
\left(\mathrm{km}^{2}\right)\end{array}$ & $\begin{array}{l}\text { (thresho } \\
\text { class. } \\
\text { pixels }\end{array}$ & $\begin{array}{c}\mathrm{d}=5 \cdot 0) \\
\text { area } \\
\left(\mathrm{km}^{2}\right)\end{array}$ & $\begin{array}{l}\text { (thresh } \\
\text { class. } \\
\text { pixels }\end{array}$ & $\begin{array}{c}\mathrm{ld}=6 \cdot 0) \\
\text { area } \\
\left(\mathrm{km}^{2}\right)\end{array}$ \\
\hline Pasture & 22824 & $20 \cdot 542$ & 22880 & $20 \cdot 592$ & 22630 & $20 \cdot 367$ & 23332 & $21 \cdot 000$ \\
\hline Capoeira & 19512 & $17 \cdot 561$ & 19621 & $17 \cdot 659$ & 24689 & $22 \cdot 290$ & 26636 & $23 \cdot 972$ \\
\hline Forest & 184369 & $165 \cdot 932$ & 187382 & $168 \cdot 644$ & 181765 & $163 \cdot 589$ & 184381 & $165 \cdot 940$ \\
\hline Fire scars & 16608 & $14 \cdot 947$ & 16613 & 14.951 & 14954 & 13.459 & 17593 & $15 \cdot 834$ \\
\hline Unclass. & 18831 & 16.948 & 15648 & 14.083 & 18106 & $16 \cdot 295$ & 10202 & $9 \cdot 182$ \\
\hline
\end{tabular}

\footnotetext{
* samples from single-cell classificartion;
}

** new samples. 
Table 2. Classification matrixes for the four spectral classes.

\begin{tabular}{|c|c|c|c|c|c|c|c|c|c|}
\hline \multirow[b]{2}{*}{ Thresh. } & \multirow[t]{2}{*}{ CLASS } & \multirow[b]{2}{*}{$\mathrm{NC}$} & \multicolumn{4}{|c|}{ Classification matrix } & \multirow{2}{*}{$\begin{array}{c}\text { Average } \\
\text { performance }\end{array}$} & \multirow{2}{*}{$\begin{array}{l}\text { Average } \\
\text { abstention }\end{array}$} & \multirow{2}{*}{$\begin{array}{l}\text { Average } \\
\text { confusion }\end{array}$} \\
\hline & & & 1 & 2 & 3 & 4 & & & \\
\hline $6 \cdot 0$ & $\begin{array}{l}1 \\
2 \\
3 \\
4\end{array}$ & $\begin{array}{l}0.0 \\
0.0 \\
0.0 \\
0.0\end{array}$ & $\begin{array}{r}99 \cdot 1 \\
0.0 \\
0 \cdot 0 \\
0.0\end{array}$ & $\begin{array}{r}0.0 \\
100.0 \\
0.0 \\
0.0\end{array}$ & $\begin{array}{r}0.9 \\
0 \cdot 0 \\
99.6 \\
0 \cdot 0\end{array}$ & $\begin{array}{r}0.1 \\
0.0 \\
0.4 \\
100 \cdot 0\end{array}$ & $99 \cdot 7$ & $0 \cdot 0$ & $0 \cdot 4$ \\
\hline $5 \cdot 5$ & $\begin{array}{l}1 \\
2 \\
3 \\
4\end{array}$ & $\begin{array}{l}0.0 \\
0.0 \\
0.0 \\
0.0\end{array}$ & $\begin{array}{r}99 \cdot 1 \\
0.0 \\
0 \cdot 0 \\
0 \cdot 0\end{array}$ & $\begin{array}{r}0 \cdot 0 \\
100 \cdot 0 \\
0 \cdot 0 \\
0 \cdot 0\end{array}$ & $\begin{array}{r}0.8 \\
0.0 \\
99.6 \\
0.0\end{array}$ & $\begin{array}{r}0.1 \\
0.0 \\
0.4 \\
100 \cdot 0\end{array}$ & $99 \cdot 7$ & $0 \cdot 0$ & $0 \cdot 4$ \\
\hline $5 \cdot 0$ & $\begin{array}{l}1 \\
2 \\
3 \\
4\end{array}$ & $\begin{array}{l}0.02 \\
0.0 \\
0.1 \\
0.2\end{array}$ & $\begin{array}{r}98.9 \\
0.0 \\
0.0 \\
0.0\end{array}$ & $\begin{array}{r}0.0 \\
99.9 \\
0.0 \\
0.0\end{array}$ & $\begin{array}{r}0.7 \\
0.0 \\
99.5 \\
0.0\end{array}$ & $\begin{array}{r}0.1 \\
0.0 \\
0.4 \\
99.8\end{array}$ & $99 \cdot 5$ & $0 \cdot 1$ & $0 \cdot 3$ \\
\hline $4 \cdot 5$ & $\begin{array}{l}1 \\
2 \\
3 \\
4\end{array}$ & $\begin{array}{l}0.5 \\
0 \cdot 1 \\
0 \cdot 4 \\
0 \cdot 2\end{array}$ & $\begin{array}{r}98 \cdot 8 \\
0.0 \\
0 \cdot 0 \\
0 \cdot 0\end{array}$ & $\begin{array}{r}0.0 \\
99.9 \\
0.0 \\
0.0\end{array}$ & $\begin{array}{r}0.6 \\
0.0 \\
99.2 \\
0.0\end{array}$ & $\begin{array}{r}0.1 \\
0.0 \\
0.4 \\
99.8\end{array}$ & $99 \cdot 4$ & $0 \cdot 3$ & $0 \cdot 3$ \\
\hline $4 \cdot 0$ & $\begin{array}{l}1 \\
2 \\
3 \\
4\end{array}$ & $\begin{array}{l}1.8 \\
1.1 \\
1.0 \\
1.2\end{array}$ & $\begin{array}{r}98 \cdot 0 \\
0.0 \\
0.0 \\
0.0\end{array}$ & $\begin{array}{r}0.0 \\
98.9 \\
0.0 \\
0.0\end{array}$ & $\begin{array}{r}0.2 \\
0.0 \\
98 \cdot 7 \\
0 \cdot 0\end{array}$ & $\begin{array}{r}0 \cdot 0 \\
0 \cdot 0 \\
0 \cdot 4 \\
98 \cdot 8\end{array}$ & $98 \cdot 6$ & $1 \cdot 3$ & $0 \cdot 2$ \\
\hline $3 \cdot 5$ & $\begin{array}{l}1 \\
2 \\
3 \\
4\end{array}$ & $\begin{array}{l}6 \cdot 2 \\
4.9 \\
6 \cdot 6 \\
5 \cdot 0\end{array}$ & $\begin{array}{r}93.9 \\
0.0 \\
0.0 \\
0.0\end{array}$ & $\begin{array}{r}0.0 \\
95.1 \\
0.0 \\
0.0\end{array}$ & $\begin{array}{r}0 \cdot 1 \\
0 \cdot 0 \\
93 \cdot 2 \\
0 \cdot 0\end{array}$ & $\begin{array}{r}0 \cdot 0 \\
0 \cdot 0 \\
0 \cdot 2 \\
95 \cdot 0\end{array}$ & $94 \cdot 3$ & $5 \cdot 7$ & $0 \cdot 1$ \\
\hline
\end{tabular}

$\mathrm{NC}=$ not classified; $\mathrm{C}=$ classified; $\mathrm{A}=$ actual

$1=$ fire scars; $2=$ tropical forests; $3=$ pastures; $4=$ 'capoeiras'

The histograms in figure 6 show the distribution of grey levels for the pixels of the class containing fire scars. It is important to notice that except for channel 5 the shape of the histograms is very narrow (small variance), with few pixels of low values of grey levels that could be mistaken with other classes. In channel 5, a large number of pixels with low grey levels occur, and these pixels correspond to scars of fires that occurred more recently regarding the date TM imaged the region. This last conclusion is based on the comparison of the TM image described in this work with that of the previous TM overpass, on 26 July 1985.

Histograms of all pixels in channels 3,4 and 5 of the sector with 512 by 512 pixels of the area studied are presented in figure 7 . In this case no attempt was made to consider distinct or main ground covers and as a result a class associated to water was also identified in channels 4 and 5. The waters in this class were those of relatively clean rivers, i.e., without major silt contamination which is now common because of gold panning. This figure also shows that TM channel 4 is the most appropriate to identify fire scars, and that water, with lower grey levels, is not mistaken for them. 
Another possibility to examine the spectral characteristics of fire scars is through the inspection of linear cross-sections of TM images containing this particular ground cover. Figure 8 contains such cross-sections for a scan line in the seven TM channels studied in the image of 11 August 1985, approximately at the centre of the 512 by 512 pixels sector. Again channel 4 shows the largest difference in digital counts for the fire scars in relation to other ground covers. Channels 3 and 7 present
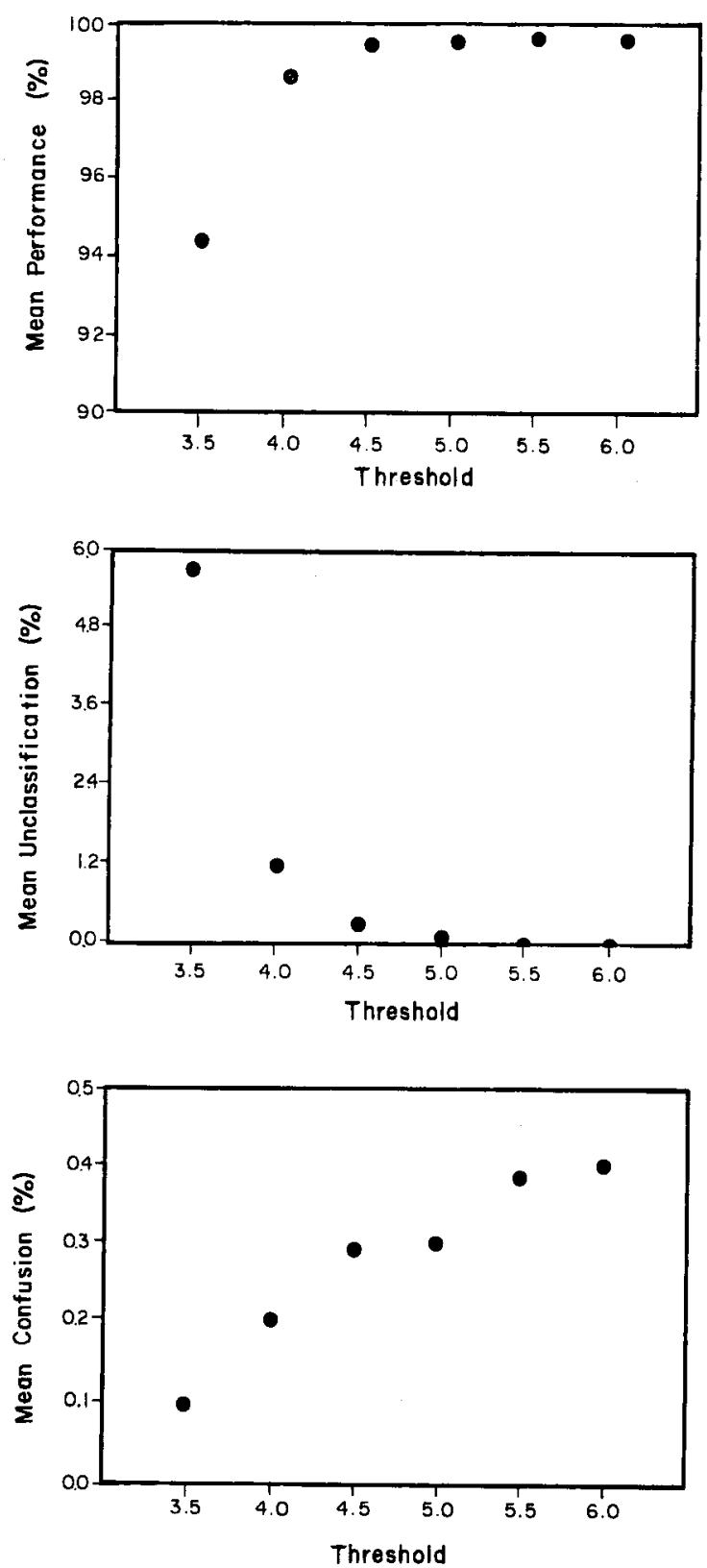

Figure 3. Results of thresholds tests of the four spectral classes. 

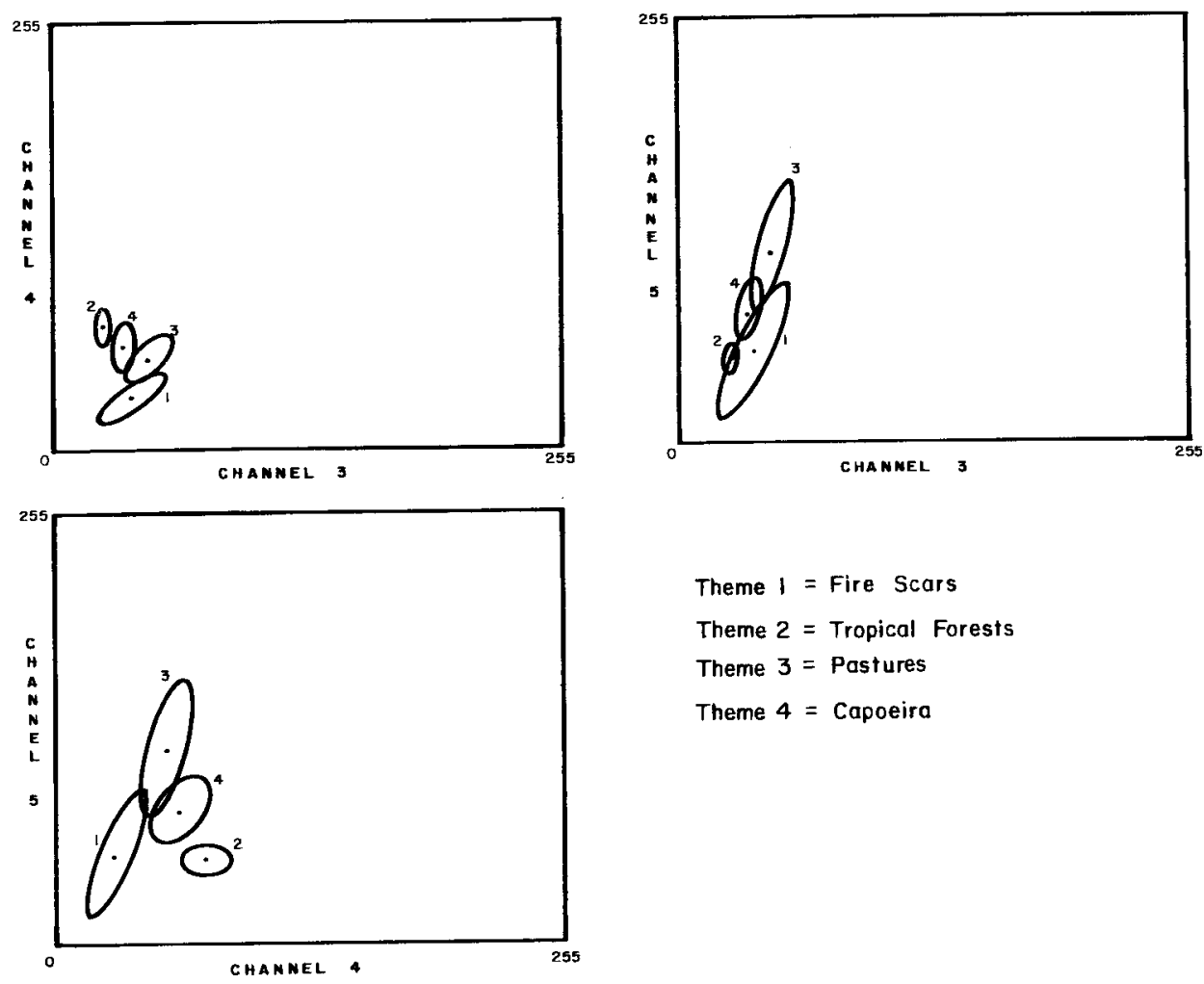

Figure 4. Space features of the four spectral classes.

approximately the same type of response to the fire scars and to other ground covers; as a consequence, considering that the troposphere in the areas of biomass burning is loaded with aerosols, the use of channel 7 is preferred since it penetrates smoke to some extent.

Channel $7(2 \cdot 08-2 \cdot 35 \mu \mathrm{m})$ also showed another relevant feature in terms of the analysis of fire scars. It was the only channel that detected active fires and fire fronts,

Table 3. Averages and variances of grey levels for the four spectral classes in the seven Landsat TM channels on 11 August 1985.

\begin{tabular}{|c|c|c|c|c|c|c|c|c|}
\hline \multirow{3}{*}{$\begin{array}{l}\text { Class } \\
\text { Number of } \\
\text { pixels } \\
\text { Statistics }\end{array}$} & \multicolumn{2}{|c|}{ Fire Scars } & \multicolumn{2}{|c|}{ Tropical Forest } & \multicolumn{2}{|c|}{ Pasture } & \multicolumn{2}{|c|}{ 'Capoeira' } \\
\hline & \multirow[b]{2}{*}{$X$} & \multirow{2}{*}{${ }^{0} s_{2}$} & \multicolumn{2}{|c|}{166589} & \multicolumn{2}{|c|}{-21086} & \multicolumn{2}{|c|}{19427} \\
\hline & & & $X$ & $s_{2}$ & $X$ & $s_{2}$ & $X$ & $s_{2}$ \\
\hline \multicolumn{9}{|l|}{ Band } \\
\hline 1 & $89 \cdot 83$ & $40 \cdot 89$ & $77 \cdot 48$ & $9 \cdot 29$ & $89 \cdot 39$ & $25 \cdot 11$ & $85 \cdot 10$ & $20 \cdot 65$ \\
\hline 2 & $37 \cdot 45$ & $16 \cdot 08$ & $30 \cdot 74$ & $2 \cdot 17$ & $39 \cdot 45$ & $11 \cdot 17$ & 35.43 & 6.99 \\
\hline 3 & $41 \cdot 97$ & $40 \cdot 06$ & $26 \cdot 27$ & $2 \cdot 20$ & $48 \cdot 23$ & $40 \cdot 64$ & $35 \cdot 31$ & $15 \cdot 85$ \\
\hline 4 & $34 \cdot 50$ & $24 \cdot 38$ & $71 \cdot 59$ & $29 \cdot 81$ & $55 \cdot 76$ & $32 \cdot 75$ & $61 \cdot 51$ & 33.89 \\
\hline 5 & $62 \cdot 27$ & 175.66 & $50 \cdot 67$ & $19 \cdot 60$ & $114 \cdot 25$ & $416 \cdot 00$ & $75 \cdot 91$ & $108 \cdot 52$ \\
\hline 7 & $36 \cdot 33$ & $147 \cdot 77$ & $9 \cdot 40$ & $2 \cdot 36$ & $36 \cdot 69$ & $104 \cdot 72$ & $85 \cdot 10$ & $20 \cdot 65$ \\
\hline 6 & $140 \cdot 46$ & $30 \cdot 97$ & $121 \cdot 60$ & $3 \cdot 52$ & $130 \cdot 74$ & $13 \cdot 13$ & $126 \cdot 44$ & $9 \cdot 63$ \\
\hline
\end{tabular}




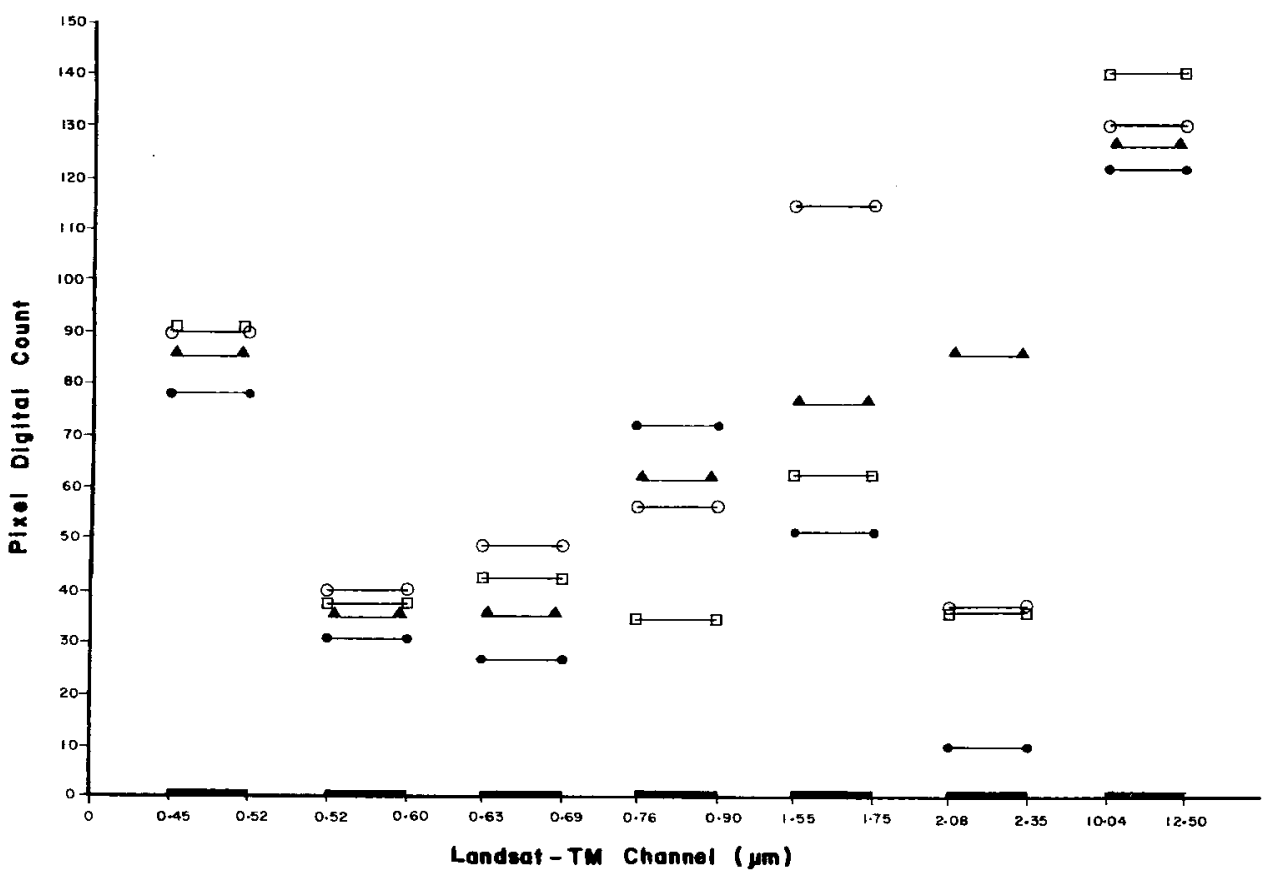

Figure 5. Mean digital counts of the four spectral classes in seven Landsat TM channels. $\boldsymbol{\bullet}$, tropical forests; $\bigcirc$, pastures; $\boldsymbol{\Lambda}$, capoeira; $\square$, fire scars.

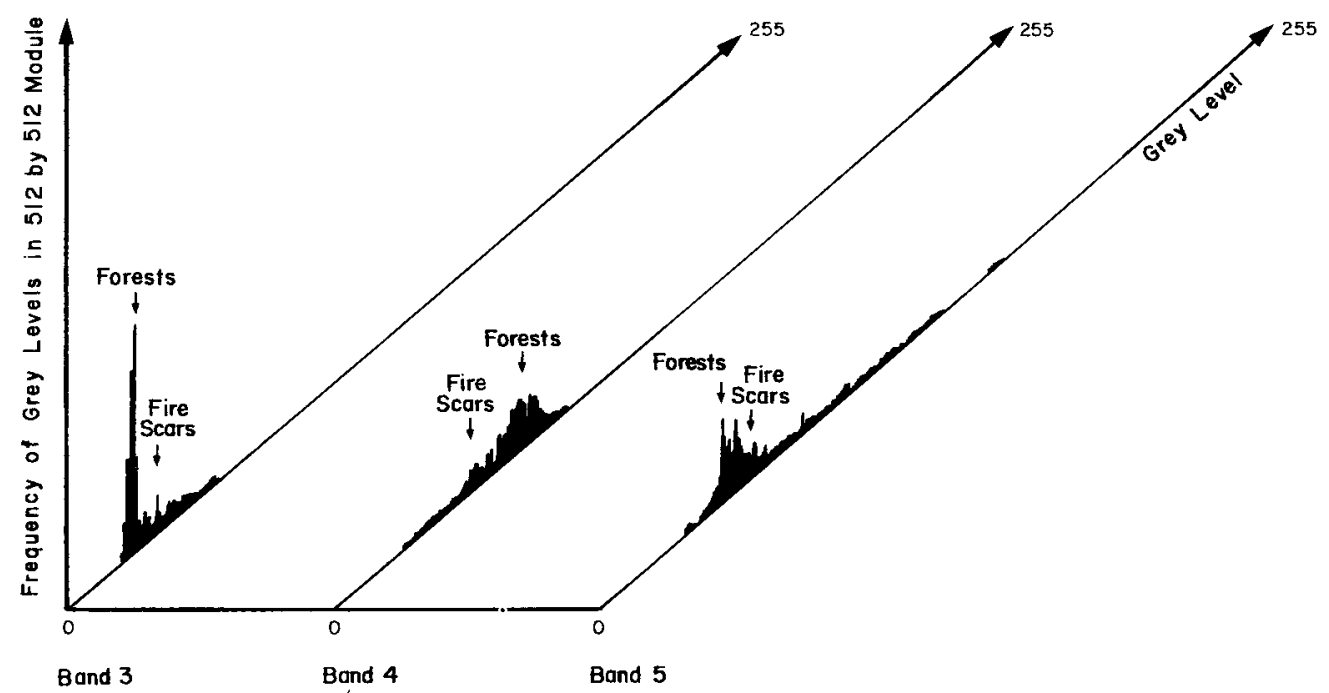

Figure 6. Frequency distribution of grey levels in the 512 by 512 sector. Maximum and minimum counts and maximum frequency of pixels, were respectively: channel 3,125 , 18, and 51 819; channel 4, 110, 20, and 12042; channel 5, 254, 25, and 19188. 


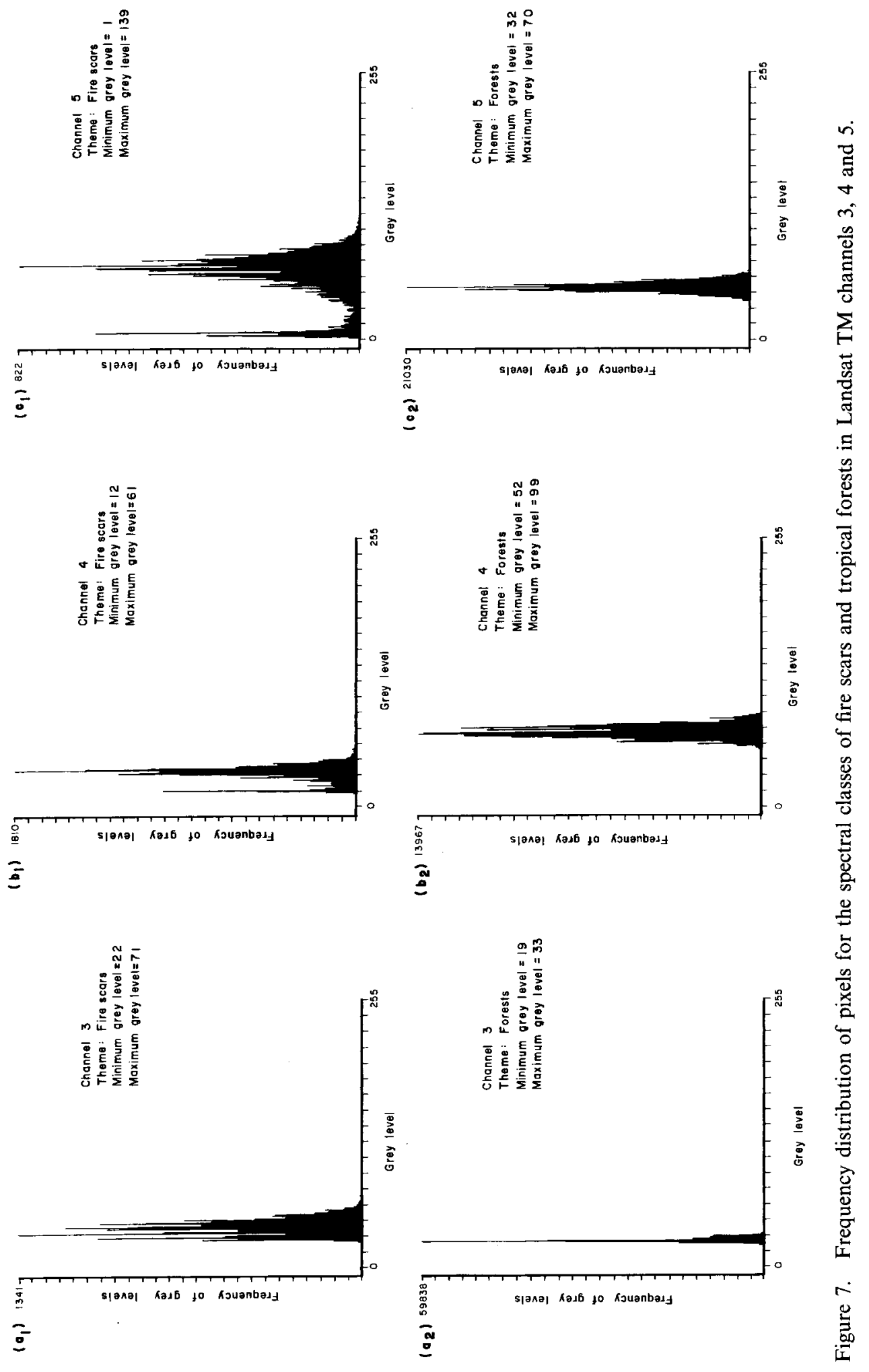



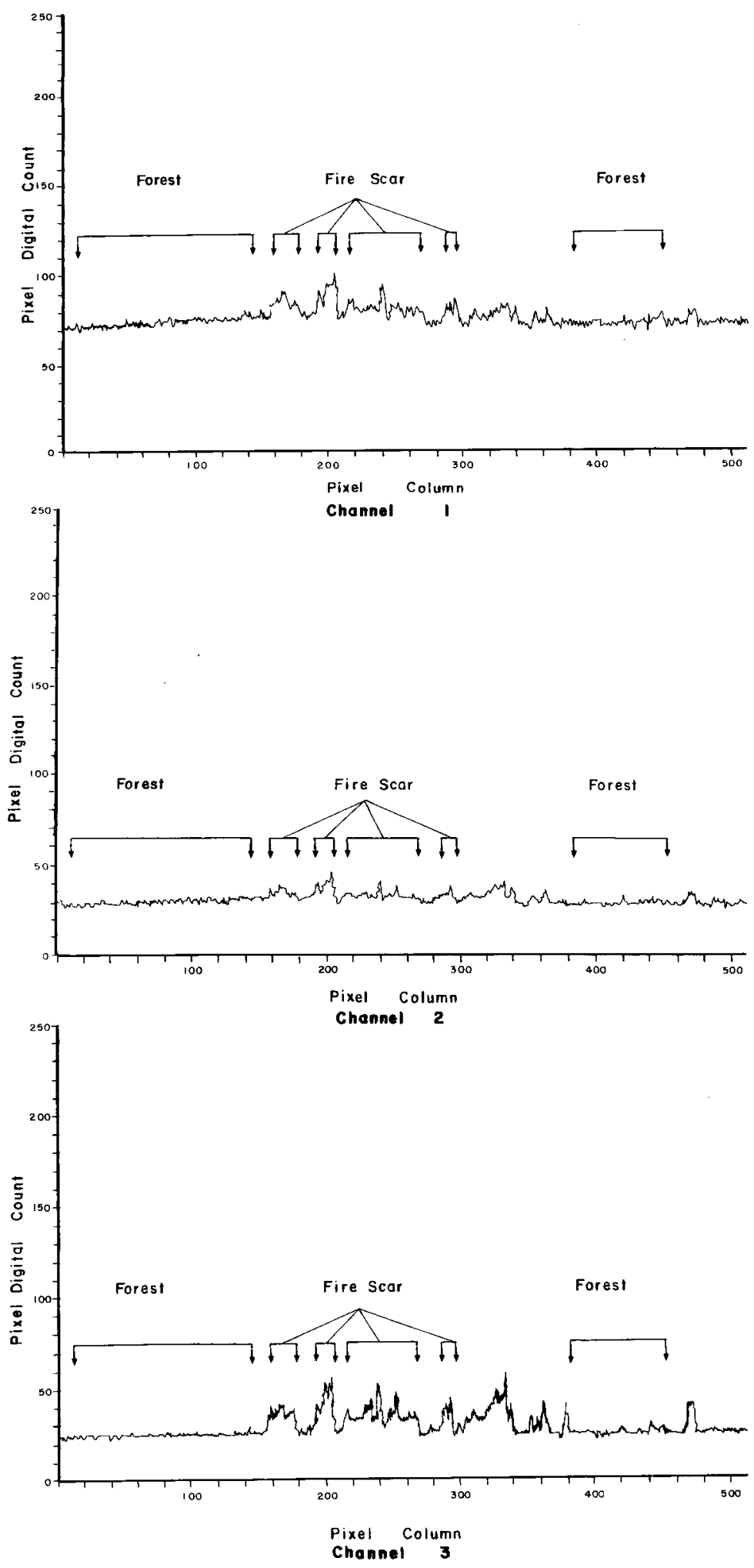

Figure 8. 

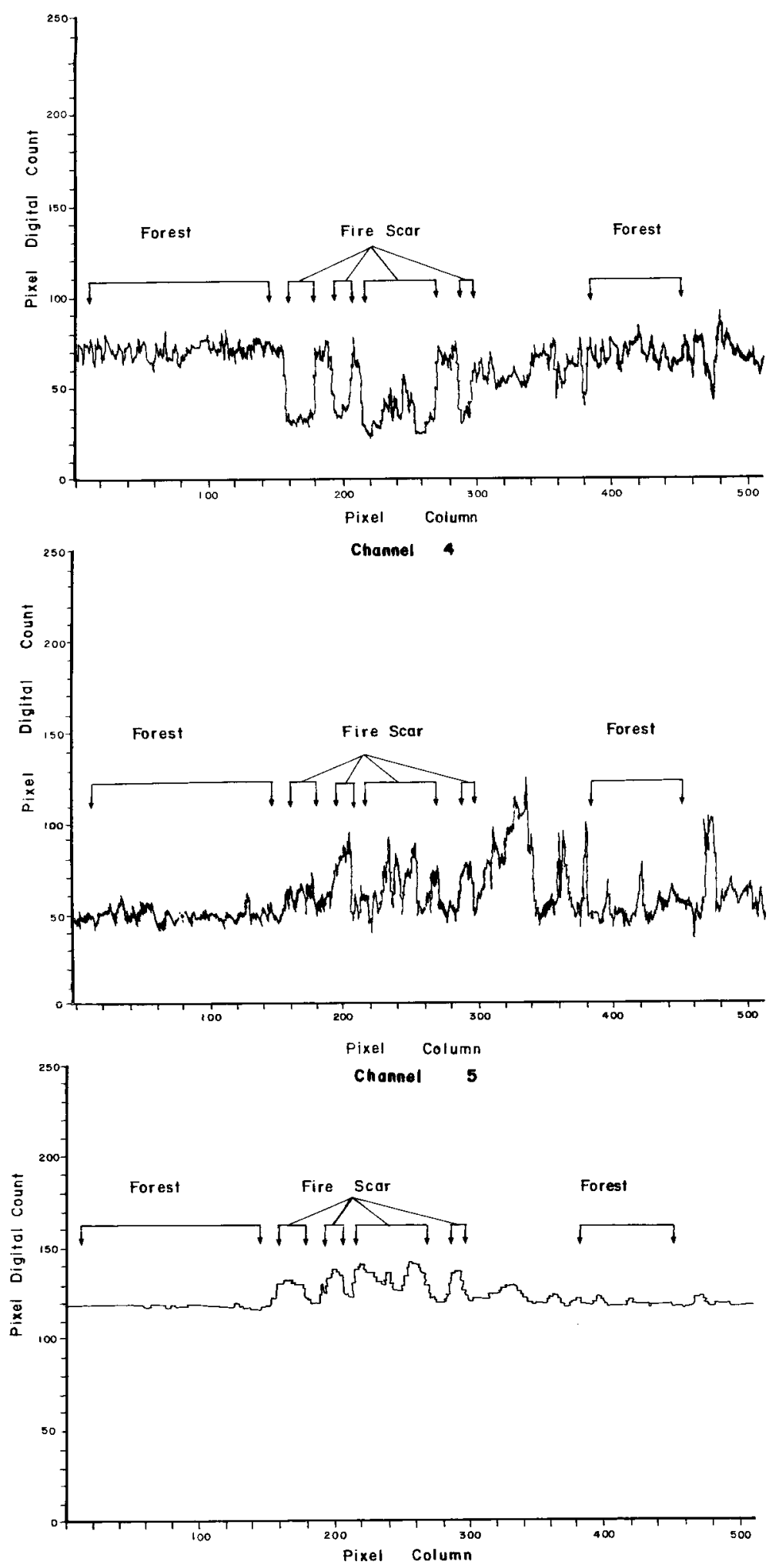

Channel 6 Figure 8. 


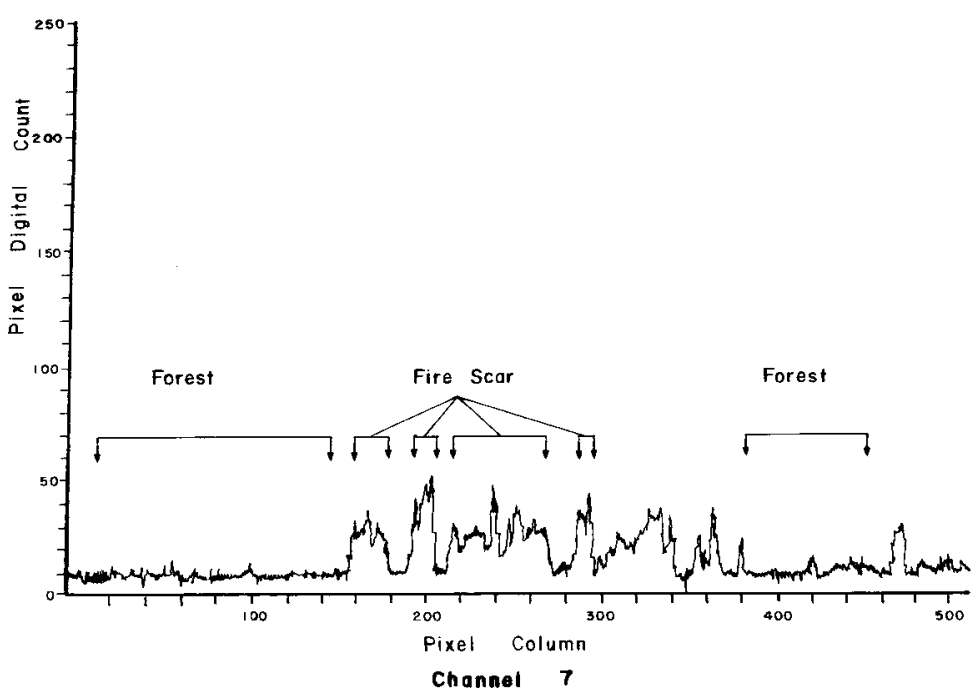

Figure 8. Pixel cross-section of fire scars in the seven Landsat TM channels.

which were depicted by pixels saturated or with digital counts close to saturation. This fact is based on the data of spectral emission of fire events summarized by Robinson (1991), who pointed out that active fires have their peak emission between $3 \mu \mathrm{m}$ and $1.6 \mu \mathrm{m}$.

Channels 1 and 2 showed the smallest digital count variation for fire scars and for other ground covers in general, suggesting that they are not the adequate channels for biomass burning detection.

In channel $6(\sim 11 \mu \mathrm{m})$ the digital counts associated to temperature have higher values in the fire scars, even if not recent. This channel was not used in the classification of fire scars since the difference in temperature in relation to surrounding areas was very small.

In the comparative analysis of the three images only data of channels 3,4 and 5 were used, since according to the text above they best characterize fire scars. Table 4 shows the comparison of statistics of pixel values for the four themes. The images of 16 July 1987 and 22 August 1989 have two columns for the pixel values. The first column, actual value, shows statistics from values obtained in the raw images; the second column, corrected value, shows statistics using the multiplying correction factor that accounts for solar elevation and distance. Each of the four classes has averages $(X)$ and variances $\left(S^{2}\right)$ for the pixel samples in the supervised definition of that class (samples), and for all pixels in the image sector belonging to that same class and automatically classified (all). Figure 9 shows the average pixel values for the four themes in the three images, using the corrected values for the last two images.

A visual examination during the processing of the three scenes showed that the one imaged in July was less hazy and fuzzy than the two from August. This was interpreted as a result of the smoke emissions from biomass burning in the region, following a seasonal pattern where the more intense fire activity occurs towards the end of August and early September (Setzer and Pereira 1991). This effect is noticed in table 4 and figure 9 for the background theme natural forests, which shows for 


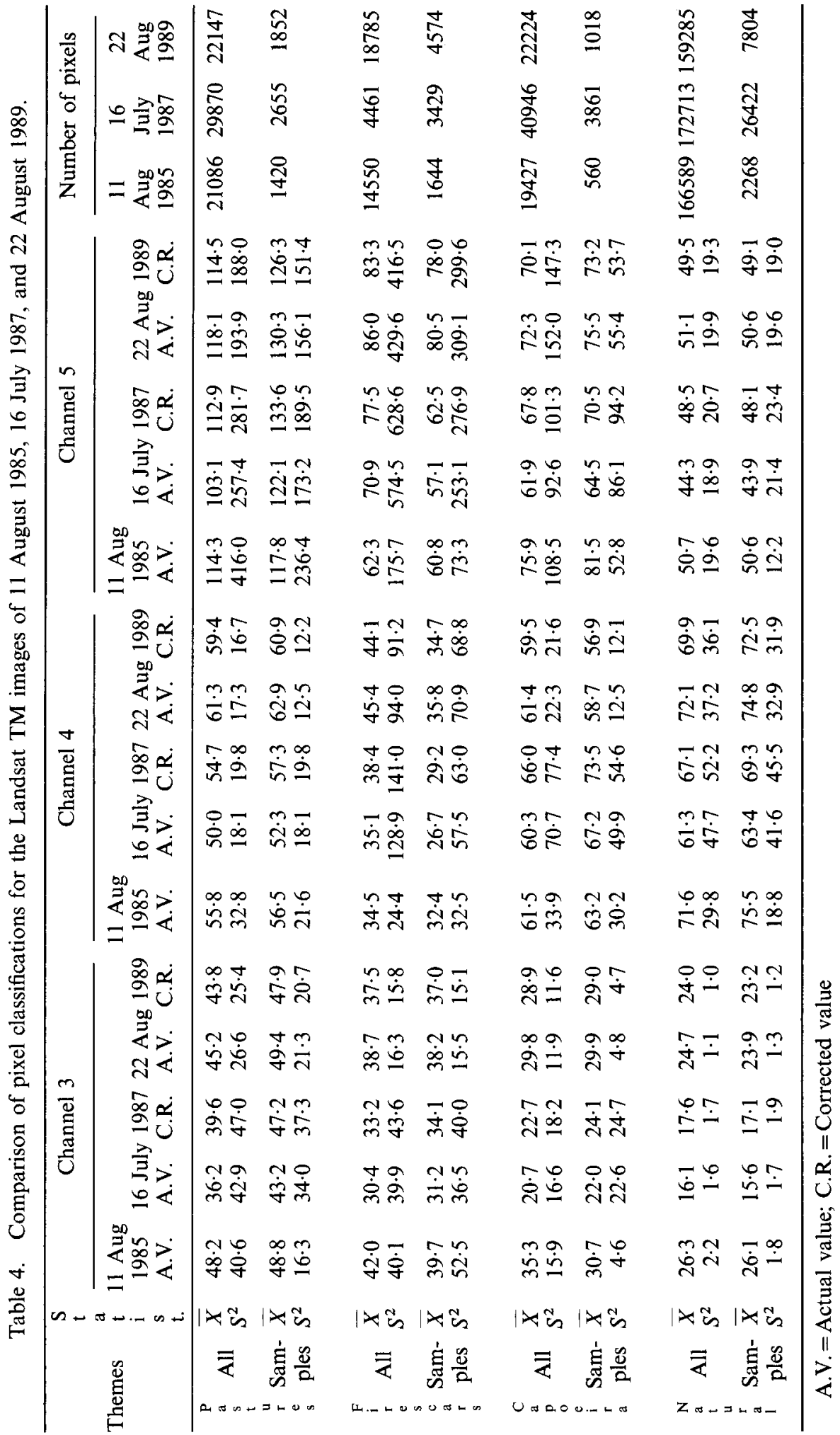


July 1987 smaller pixel values than for August 1985 and August 1989. The maximum differences in pixel average counts for channels 3,4 and 5 were $8 \cdot 7,4 \cdot 5$, and $2 \cdot 2$, respectively, indicating that attenuation of the radiance measured by the TM was about 33 per cent for channel 3, 6 per cent for channel 4, and 4 per cent for channel 5 . These results are very much in agreement with the concept that the largest the

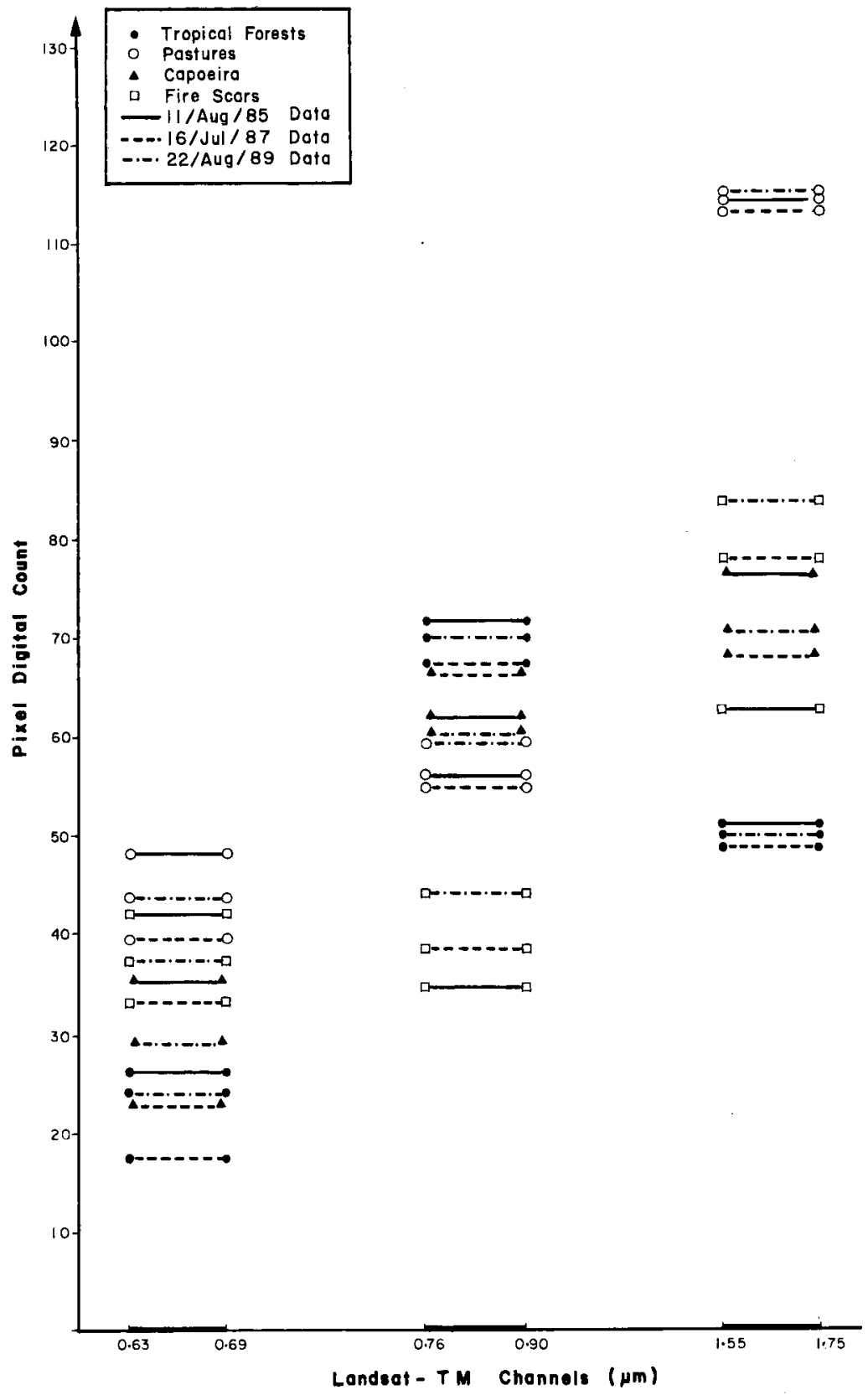

Figure 9. Averages of digital counts in Landsat TM channels 3, 4, and 5 for the four spectral classes in the images of 11 August 1985, 16 July 1987, and 22 August 1989. 
light wavelength the largest the capability of smoke penetration, and could be used to calculate total loads of aerosols in the atmosphere when combined to equations of optical turbidity. The other three themes also showed large ranges of pixel values in channel 3 when compared to channels 4 and 5 because of the effect of smoke. Pixels of fire scars in channel 5 presented a much wider range (62.3 to 83.3) than pixels in the other themes for this channel; this was interpreted as a consequence of an ageing effect, since relatively old fire scars tend to have more exposed soil than recent ones, and therefore reflect more radiation. TM channel 4 , when considering the temporal and smoke effects, also showed the best definition of fire scar pixels ( 34.5 to $44 \cdot 1$ ), without any radiometric confusion with other themes.

\section{Conclusions}

Fire scars in areas of deforestation in Amazonia were detected in Landsat-5 TM images. Channel $4(0 \cdot 76-0.90 \mu \mathrm{m})$ was the most appropriate one to discriminate the scars from other ground covers. Average digital count of 14550 pixels of fire scars in channel 4 were 21 grey levels below the count of other ground covers; this difference dropped to 12 in channel 5, to 10 in thermal channel $6(10.04-12.50 \mu \mathrm{m})$, and to 6 in channel 3. Its use, either isolated, or in combination with other TM channels is necessary to detect fire scars.

Channel $5(1.55-1.75 \mu \mathrm{m})$ also discriminated fire scars from other ground covers, and showed different spectral characteristics for recent and aged fire scars. Recent scars in this channel were easily mistaken with water bodies, and its use must be accompanied by cross-checking information of other TM channels, particularly of channel 4.

TM channels $1(0.45-0.52 \mu \mathrm{m}), 2(0.52-0.60 \mu \mathrm{m})$ and $3(0.63-0.69 \mu \mathrm{m})$ were the best to detect smoke plumes from active fires and smouldering areas. TM channel 7 $(2.08-2.35 \mu \mathrm{m})$ detected the active fires present in the image, which could not be detected in any of the other TM channels.

A comparison with two other images in different dates corroborated the use of TM channel 4 as the most adequate to monitor fire scars. Smoke from biomass burning caused radiance reflection increasing the signal in channel 3 by 33 per cent, by 6 per cent in channel 4 and by 4 per cent in channel 5 .

\section{Acknowledgments}

The authors acknowledge the scholarship support of CNPq and FAPESP, the technical support of INPE/DOP and INPE/DRH, and the personal information provided by the late Armando P. Santos.

\section{References}

Allan, G. E., 1984, Criteria for the remote sensing bushfire history, current fuel load and fire behaviour in Central Australia. In Australian Remote Sensing Conference, 3, Queensland, Australia, 21-25 May, (Brisbane, Australia: Organising Committee of Landsat84), pp. 275-280.

Bruneau, M., and LE TOAN, T., 1978, An interpretation of Northern Thailand swiddening and multiple cropping system using multidate Landsat images and computer compatible tapes. In International Symposium on Remote Sensing of Environment, 12, 20-26 April, (Ann Arbor, MI: ERIM, V.3), pp. 1883-1893.

Brustet, J. M., Vickos, J. B., Fontan, J. Podaire, A., and Lavenu, F., 1991, Characterization of active fires in West African savannas by analysis of satellite data: Landsat 
thematic mapper. In Global Biomass Burning: Atmospheric, Climatic, and Biospheric Implications, edited by J. S. Levine, (Cambridge: MIT), pp. 53-60.

Chen, S. C., Shimabukuro, Y. E., and Hernandez, F. P., 1979, The mapping of burned area in forestry by IMAGE-100. (São José dos Campos, SP: INPE), pp. 9. (INPE-1431RPE/009).

Chuvieco, E., and Congalton, R. G., 1988, Mapping and inventory of forest fires from digital processing of TM data. Geocarto International, 4, 41-53.

Crutzen, P., and Andreae, M. O., 1990, Biomass burning in the tropics: impact on atmospheric chemistry and biogeochemical cycles. Science, 250, 1669-1678.

DeschleR, W., 1974, An examination of the extent of fire in the grassland and savanna of Africa along the Southern side of the Sahara. In International Symposium on Remote Sensing of Environment, 9, 15-19 April, (Ann Arbor, MI: ERIM, V.1), p. 22-30.

EOSAT, 1988, The Yellowstone wild fires of 1988. EOSAT, Landsat Data Users Notes, 3, (Lanham, MD: EOS Company), p. 2.

ESA, 1987, Detection of forest fires in Catalonia from TM images. Earth Observation Quarterly, 17, 5-6.

GE, 1975, IMAGE-100 user manual. (Daytona Beach, FL: General Electric Company), p. 159.

Hall, D. K., Ormsby, J. P., Johnson, L., and Brown, L., 1980, Landsat digital analysis of the initial recovery of burned tundra at Kokolik River, Alaska. Remote Sensing of Environment, 10, 263-272.

Helfert, M. R., and Lulla, K. P., 1990, Mapping continental-scale biomass burning and smoke palls over the Amazon Basin as observed from the Space Shuttle. Photogrammetric Engineering and Remote Sensing, 56, 1367-1373.

MinNiCH, R. A., 1983, Fire mosaics in Southern California and Northern Baja California. Science, 219, 1287-1294.

Pereira, M. C., Amaral, S., Zerbini, N. J., and Setzer, A. W., 1990, Estimativa da área total queimada no Parque Nacional das Emas com o uso de imagens da banda 3 do AVHRR: comparação com estimativas do TM/Landsat. In Simpósio Brasileiro de Sensoriamento Remoto, 6, 24-29 June, (S.J. Campos, SP: INPE/MCT, V.2), pp. 302310, (In Portuguese).

Pereira, M. C., and Setzer, A. W., 1992, Spectral characteristics of deforestation fires in NOAA/AVHRR images. International Journal of Remote Sensing, 14, 583-597.

Ponzoni, F. J., Lee, D. C. L., and Hernandez, F. P., 1986, Avaliação da área queimada e da regeneração da vegetação afetada pelo fogo no Parque Nacional de Brasília através de dados do Landsat TM. In Simpósio Brasileiro de Sensoriamento Remoto, 4, 10-15 August, (Gnamado, RS: INPE/SELPER/SBC, V.1), pp. 615-621, (In Portuguese).

RICHARDS, J. A., 1984, Thematic mapping from multitemporal image data using the principal components transformation. Remote Sensing of the Environment, 16, 35-46.

RichardS, J. A., and MiLne, A. K., 1984, Mapping fire burns and vegetation regeneration by classification of multitemporal Landsat MSS image data. In Australian Remote Sensing Conference, 3, Gold Coast, Queensland, 21-25 May, (Brisbane, Australia: Organising Committee of Landsat-84), pp. 304-314.

Robinove, C. J., 1975. Worldwide disaster warning and assessment with Earth Resources Technology Satellites. In International Symposium on Remote Sensing of Environment, 10, Ann Arbor, MI; 6-10 Oct., (Ann Arbor, MI: ERIM, V.2), pp. 811-820.

Robinson, J. M., 1991, Fire from space: Global fire evaluation using infrared remote sensing. International Journal of Remote Sensing, 12, 3-24.

Santos, A. P., and Novo, E. M. L. M., 1977, Uso de dados do Landsat-1 na implantação, controle e acompanhamento de projetos agropecuários no sudoeste da Amazônia legal. MSc. dissertation, S. J. Campos, SP, INPE, (INPE-1044-TPT/056), in Portuguese.

Santos, J. R., and Aoki, H., 1978, Monitoramento do Parque Nacional de Brasília, atravé de imagens orbitais. In Simpósio Brasileiro de Sensoriamerito Remoto, 1, November 1978 , (S. J. Campos, SP: CNPq/INPE, V.1), pp. 118-134.

SCHOWENGERDT, R. A., 1983, Techniques for image processing and classification in remote sensing (Orlando, Fl: Academic Press).

Setzer, A. W., and Pereira, M. C., 1991, Amazonia biomass burnings in 1987 and an estimate of their tropospheric emissions. Ambio, 20, 19-22. 
TAnaKa, S., Kimura, H., and Suga, Y., 1983, Preparation of 1:25000 Landsat map for assessment of burned area of Etajima Island. International Journal of Remote Sensing, 4, 17-31.

USGS NOAA, 1984, Landsat-4 data users handbook. (Alexandria, VA: USGS), p. 242.

Velasco, F. R. D., Prado, L. O. C., and Souza, R. C. M., 1979, Sistema MAXVER: manual de descriçào de programas. (S. J. Campos, SP: INPE/CNPq) (INPE-1499-RPI-004), in Portuguese.

Wightman, J. M., 1973, Detection, mapping and estimation of rate spread grass fires from Southern African ERTS-1 imagery. In Symposium on significant results obtained from the ERTS-1, (New Carrolton, MD: GSFC) V.1A, pp. 593-601.

WRI, 1992. World Resources, 1992-93-A guide to the global environment. (New York: Oxford University Press). The World Resources Institute/UNEP/UNDP. 